\title{
Alone or Not Alone? - The Attitudes of Hungarians Towards Solo Travel
}

Ildikó Ernsz†

The University of Pannonia Nagykanizsa, University Center for Circular Economy, Hungary

Zsuzsanna Marton

The University of Pannonia Nagykanizsa, University Center for Circular Economy, Hungary

\footnotetext{
Abstract this type of traveling are.

Keywords: solo travel, tourism trends, motivations

JEL classification: Z32

Paper type: Research article

Received: Mar 13, 2021

Accepted: Jun 07, 2021

DOI: $10.54820 / D G P S 9412$
}

Before the COVID pandemic, solo travel was getting more and more popular especially among women travelers. Both demographic, social trends, and inner motivations enhanced the popularity of this type of travel. The aging society and the single lifestyle increased the demand on the one hand, while on the other hand, the desire for self-realization, to find new ways of life, escapism, the thirst for selfconfidence drive more tourists to travel alone. In the case of women travelers, their increasing decisive power and independence also boosted solo travel. The tourism industry also offers several attractions specially designed for them. The postpandemic era will show how this special group of travelers will react to the changed circumstances and how they will change their travel habits. The paper examines how frequently Hungarian respondents travel alone and what their attitudes towards 


\section{Introduction}

The social and economic changes of the last decades have thoroughly redrawn the map of travel habits. An increasing number of people live alone, single - either voluntarily or from necessity. This trend is also reflected in the type of travel. Before the COVID19 pandemic, more and more travelers belonged to this group, who traveled alone (Cohen et al., 2015; Bianchi, 2016; Her et al., 2018, Brown et al., 2020, Devajyoti, 2014).

For today, solo traveling has created a special segment of the tourism market. This segment has got into the focus of different tourism service providers, but also of academic researchers. The topic has induced several pieces of research and studies (Marton et al., 2020). Solo travelers have also their preferences. The tourism industry has revealed them already and tries to attract this segment by giving special offers for them. They would like to have more tours, accommodations with no single supplement; hotels with more single rooms with special rates for solo guests, communal tables at restaurants creating the possibility for dining with other solos, or welcome receptions and parties for solo travelers (Solo Traveler, 2018b).

To goal of the paper is to investigate the attitudes of Hungarians towards solo travel. Survey research has been used to collect information about the attitudes and solo traveling of Hungarian citizens.

\section{Background}

There are several trends in society that fuel solo travel (See Figure 1). It is interesting to see, that $60 \%$ of solo travelers live in a relationship: by traveling alone they want to keep control in their affairs, in their own life (Martin, 2018).

Figure 1

Different trends in society fueling solo travel

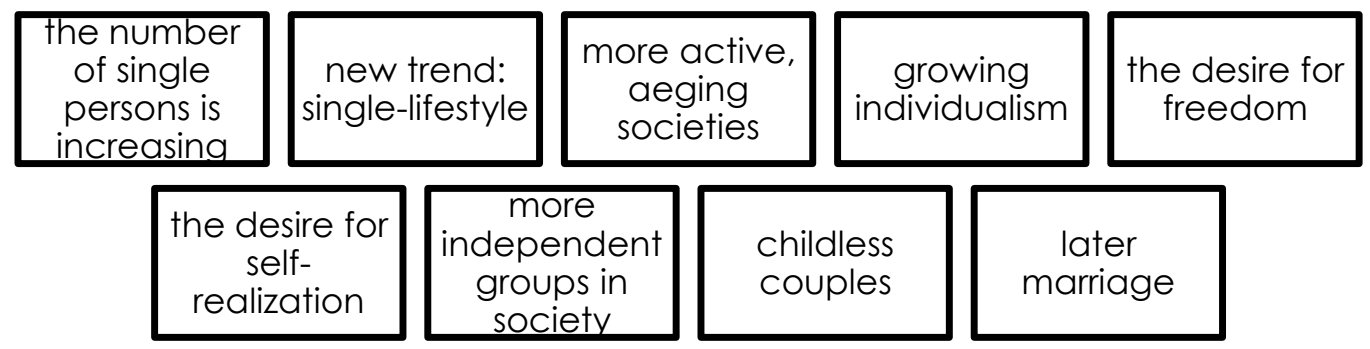

Source: Ernszt-Marton (2020), Laesser et al. (2007)

Leith (2020) identifies the following basic drivers of solo tourism: "the search for solitude; the search for social interaction; lessening of the solitary stigma; and the digital anchor to others". "Curious hedonism" and social matters are also considered to be the main drivers (Leith, 2020, Laesser et al., 2007). Curious hedonism means, that solo travelers want to experience and discover new things - insisting on convenience (Laesser et al., 2007). "Difficulty in finding a travel companion" and a "free choice" were also considered to be reasons for solo travel (Abbasian, 2018).

The Solo Traveler has surveyed in 2018 . Based on its results $58,9 \%$ of solo travelers travel alone, because "they want to see more of the world, and don't want to wait for others; $45,39 \%$ want to be independent of others, since they "want to do what they want when they want", finally $27,69 \%$ like independence, because" it grows their self-confidence" (Solo Traveler, 2018a). Traveling solo has several advantages, but disadvantages as well (See Table 1). 
Table 1

Advantages and disadvantages of solo travel

\begin{tabular}{ll}
\hline \multicolumn{1}{c}{ Pros of solo travel } & \multicolumn{1}{c}{ Cons of solo travel } \\
\hline opportunity for personal growth & taking higher costs \\
setting your own schedule & getting lonely \\
giving time to you to think & more dangerous \\
having more chance to cultural interaction & discomfort increases \\
immersion experience & cannot share experiences \\
\hline
\end{tabular}

Source: Ernszt et al. (2020) based on Julieff (2019), Crawford (2019)

Several other pieces of research revealed different aspects of solo travel. Brown et al. (2020) explored the experiences of solo tourists regarding dining since people traveling alone cannot avoid dining alone. They felt stigmatized by other guests and workers of the restaurants because negative feelings were sent for them because of them being alone. Having dinner alone was the worst of the meals since it is a time for socialization; furthermore, being a solo woman strengthened the discomfort feeling.

However, there are still several circumstances, obstacles that make the travels of women harder. Meanwhile, solo female travelers have got into the spotlight. There is no doubt that women have become equal with their male colleagues not only in the world of work but also in the world of travel. Today, as an almost cliché, we repeat that a significant proportion of travel decisions are made by women (Bond, 2021).

The fact that women travel alone is due to a great many factors, with many desires and circumstances behind it (See Figure 2). The topic of motivations, drivers is deeply a researched area. The researchers have revealed several typical motivational drivers of women traveling solo.

Figure 2

The motivational drivers of women solo travel

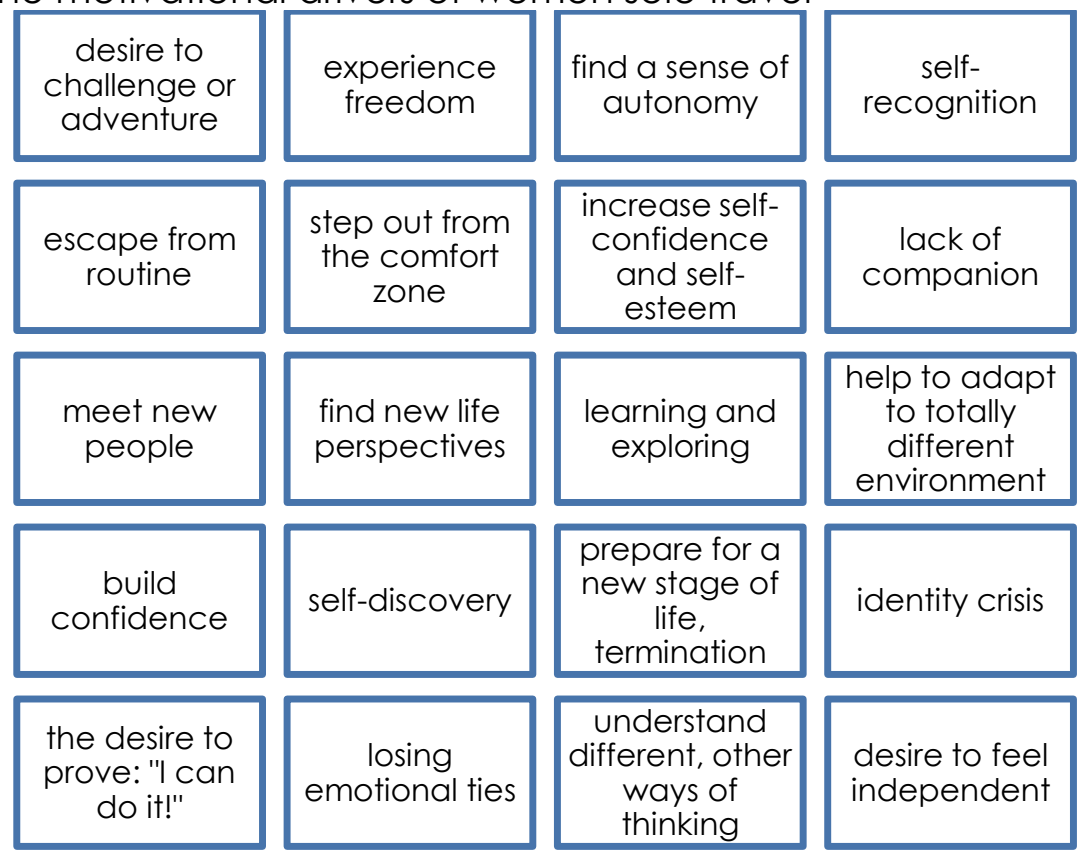

Source: Own compilation based on Marton et al. (2020), Wilson et al. (2008), Willson et al. (2006), McNamara et al. (2010), Jordan et al. (2005), Chiang et al. (2006), Seow et al. (2018), Ernszt et al. (2020) 
According to Osman et al. (2019), travel motivations can be grouped into two main factors: "personal" (e.g. freedom, flexibility, self-empowerment, independence, exploration) and "social interaction" (lack of companion, meeting new people) factors (Osman et al., 2019). Disappointment with group travel and the lack of a partner can also be reasons to travel alone for women (Mani et al., 2020).

Solo women travelers cannot be considered to be one homogenous group, they form a quite heterogeneous group (Khoo-Lattimore et al., 2018). Five motivation dimensions were identified by Chiang et al. (2006): experience, escape, relax, social, and self-esteem.

However, traveling alone as a woman has many challenges. Galik (2018) collected the barriers in solo and all women travel in her country, India. The following constraints were identified by her based on her researches (See Table 2).

Table 2

Constraints of women solo travel

\begin{tabular}{ll}
\hline Dimension & Elements \\
\hline Safety and security & $\begin{array}{l}\text { sexual assault, rapes, kidnapping and theft, eve teasing, } \\
\text { problem: being physically unfit } \\
\text { Sociocultural }\end{array}$ \\
$\begin{array}{l}\text { Individualized } \\
\text { members, colleagues, role of life partner }\end{array}$ \\
$\begin{array}{l}\text { self-concept, confidence level, loneliness } \\
\text { lack of money and time, holidays from job, lack of } \\
\text { information, language problems } \\
\text { Geographic }\end{array}$ \\
$\begin{array}{l}\text { destination specific problems, curtailed choice of } \\
\text { destinations }\end{array}$ \\
\hline
\end{tabular}

Source: Galik (2018), p. 30, Mani et al. (2020)

Solo traveler women can face barriers before (e.g. being physically unfit, financial problems) and during their travel (e.g. verbal harassment) (Mani et al., 2020). However, she found, that women could negotiate all their arising problems during their travel, which made them feel more self-confident. Solo travel has even transformed their life and was inspiring for them (Mani et al., 2020).

\section{Methodology}

To reveal the experiences and attitudes of tourists towards solo traveling, we conducted empirical research among Hungarians in 2019. The survey focused on questions regarding the popularity and the general attitude of the survey participants towards solo tourism, the benefits and the disadvantages of this type of trip.

The following research questions were drafted:

- RQ1: How popular is solo tourism among Hungarians?

- RQ2: How do the respondents evaluate the characteristics of solo tourism? What pros and cons are associated?

The survey questions and statements were drawn from the theoretical overview and earlier empirical researches (Wilson et al., 2005; Seow et al., 2018). The research participants had to answer yes-no questions and evaluate statements of the 5-point Likert scale, which is validated based on earlier research on the topic (Chiang et al., 2006). The analysis and the introduction of the survey results were based on descriptive statistics such as frequency tables and cross tabs.

In the online survey, 386 Hungarian respondents participated. Regarding the demographics of the survey sample (Table 3), 71,2 percent of the respondents were female, 28,8 percent were male. About 90 percent of the participants were under 46 
years, even 69,9 percent belong to the youngest age group (18-25 years). The age composition of the sample contributes to getting more reliable results; hence, solo tourism is rather preferred among younger generations. One of the known limitations of the research is the non-representativeness of the sample for the Hungarian population.

Table 3

Demographic profile of the sample

\begin{tabular}{|c|c|c|c|c|c|c|c|}
\hline & $\mathbf{n}$ & $\%$ & & & $\mathrm{n}$ & $\%$ & \\
\hline Age group & & & & Gender & & & \\
\hline 18-25 years & 270 & 69,9 & $\%$ & female & 275 & 71,2 & $\%$ \\
\hline $26-35$ years & 32 & 8,3 & $\%$ & male & 111 & 28,8 & $\%$ \\
\hline $36-45$ years & 45 & 11,7 & $\%$ & & & & \\
\hline $46-55$ years & 21 & 5,4 & $\%$ & Education & & & \\
\hline $55-65$ years & 13 & 3,4 & $\%$ & Primary school & 11 & 2,8 & $\%$ \\
\hline \multirow[t]{2}{*}{$>65$ years } & 5 & 1,3 & $\%$ & Secondary school & 302 & 78,2 & $\%$ \\
\hline & & & & College/ university & 70 & 18,1 & $\%$ \\
\hline Occupation & & & & Postgraduate/ PhD & 3 & 0,8 & $\%$ \\
\hline Student & 240 & 62,2 & $\%$ & & & & \\
\hline Entrepreneur & 9 & 2,3 & $\%$ & Frequency of travel & & & \\
\hline $\begin{array}{l}\text { Public sector } \\
\text { employee } \\
\text { Private sector }\end{array}$ & 42 & 10,9 & $\%$ & not every year & 8 & 2,1 & $\%$ \\
\hline employee & 88 & 22,8 & $\%$ & 1-2 times a year & 238 & 61,7 & $\%$ \\
\hline Retired & 1 & 0,3 & $\%$ & 3-4 times a year & 87 & 22,5 & $\%$ \\
\hline Other & 5 & 1,3 & $\%$ & $>4$ times a year & 53 & 13,7 & $\%$ \\
\hline
\end{tabular}

Source: The Authors' work

\section{Results}

A significant part of the respondents had decisive travel experiences, which also contribute to the more reliable results. 61,7 percent of them travel once or two times a year, 36,2 percent travel at least three or four times yearly. Regarding the motivations of their travels, the Hungarians travel most often for VFR $(59,3 \%)$, waterside holidays (52,1\%), and shopping (39,9\%). Hiking, pilgrimage, and discovering new cultures are more rarely among the travel motivations, however, precisely the above-mentioned motivational factors are more associated with solo tourism.

People who participated in the survey travel the most often with their family or friends. Solo tourism has not been so attractive to the respondents yet, 44,3 percent of them have never traveled alone. Approx. 17 percent of the Hungarian respondents travel alone often or very often. Men prefer solo trips than women, male respondents represent a higher proportion $(23,4 \%)$ in this regard than the females $(14,9 \%)$.

Solo traveling provides many advantages, but also the disadvantages also have to be considered, which determines the willingness for solo traveling (Table 4). 73, 1 percent agree or strongly agree, that solo traveling is a good opportunity to escape 
from the daily routine and working weekdays. A similar proportion of them $168,7 \%$ and $68,1 \%$ ) think that traveling alone satisfies the desire for freedom and adventure. Furthermore, there is significantly a strong agreement regarding the benefits of solo tourism in case of the following features: "having more time for myself" $(61,1 \%)$, "good "tool" to find myself and set new goals" (58\%) and "no adoption to other companions" (57,3\%).

However, the respondents do not think that solo traveling is as safe as traveling with companions. 65 percent of the survey participants believe that traveling alone has more risks.

Table 4

The evaluation of the characteristics of solo traveling

\begin{tabular}{|c|c|c|c|c|c|}
\hline Statements & (1) & $(2)$ & (3) & (4) & (5) \\
\hline No adaption to others & $6,5 \%$ & $9,1 \%$ & $27,2 \%$ & $30,1 \%$ & $27,2 \%$ \\
\hline It is as safe as the travel with others & $29,3 \%$ & $36,0 \%$ & $22,5 \%$ & $8,0 \%$ & $4,1 \%$ \\
\hline $\begin{array}{l}\text { Meeting new people and getting new } \\
\text { friendships. }\end{array}$ & $4,7 \%$ & $11,4 \%$ & $33,9 \%$ & $36,8 \%$ & $13,2 \%$ \\
\hline Having more time for myself. & $3,4 \%$ & $8,3 \%$ & $27,2 \%$ & $32,6 \%$ & $28,5 \%$ \\
\hline Becoming more confident. & $5,2 \%$ & $13,7 \%$ & $30,1 \%$ & $28,8 \%$ & $22,3 \%$ \\
\hline $\begin{array}{l}\text { It is good when having no partners to } \\
\text { travel with. }\end{array}$ & $10,6 \%$ & $14,5 \%$ & $31,6 \%$ & $26,2 \%$ & $17,1 \%$ \\
\hline Taking adventure. & $1,8 \%$ & $5,4 \%$ & $24,6 \%$ & $41, \%$ & $26,4 \%$ \\
\hline $\begin{array}{l}\text { For the need for change and } \\
\text { transformation. }\end{array}$ & $7,5 \%$ & $20,7 \%$ & $34,7 \%$ & $24,6 \%$ & $12,4 \%$ \\
\hline To find myself and set new goals. & $5,2 \%$ & $11,1 \%$ & $25,6 \%$ & $35,5 \%$ & $22,5 \%$ \\
\hline Satisfying the desire for freedom. & $1,8 \%$ & $7,8 \%$ & $21,5 \%$ & $39,6 \%$ & $29,0 \%$ \\
\hline $\begin{array}{l}\begin{array}{l}\text { Possibility to escape from the } \\
\text { weekdays. }\end{array} \\
\text { w }\end{array}$ & $1,0 \%$ & $4,9 \%$ & $21,0 \%$ & $31,1 \%$ & $42,0 \%$ \\
\hline
\end{tabular}

Note: 1 -Strongly disagree, 2- disagree, 3 - Undecided, 4 - Agree, 5 -Strongly agree Source: Authors' edition

However, the participants justified the advantages of solo tourism with a high proportion of agreement: most of them $(75,9 \%)$ do not plan to travel alone in the future. Many reasons can contribute to and confirm this result. 86,6 percent of the Hungarian respondents think that sharing and living travel experiences with others are important, therefore they would rather not take solo trips. Besides this, they would also miss their families, and on the other hand, the family would not support the idea of solo travel either.

As it was detailed in the literature review, women create a special segment in solo tourism. Comparing the replies of females to the answers of male respondents, the results show, that there is a significant difference between them according to the One-way ANOVA analysis. Women are more sensitive to safety and security issues than men on a 5 percent significant level $(p=0,17<0,05)$, even though both females $(m=2,13)$ and males $(m=2,42)$ think that traveling alone cannot be as safe as traveling with companions. A remarkable difference was also detected in the case of the following drivers and aspects of solo traveling: the need for change $(p=0,08)$, self-actualization (to find myself and set new goals) $(p=0,00)$. Based on the results women find the spiritual and abstract approach of solo tourism more important than men. 
Figure 3

Reasons behind refuse of solo travel

I want to share experiences with others.

$\begin{array}{lll}.19 \% & 23,0 \% & 63,6 \%\end{array}$

I would miss my family.

No support from family/ friends' side.

\section{$.1 \%, 5 \%$} $23,0 \%$ $63,6 \%$

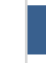

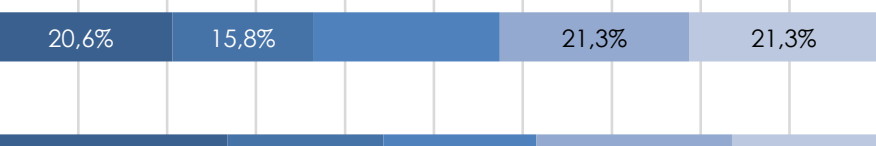

Safety and security reasons.

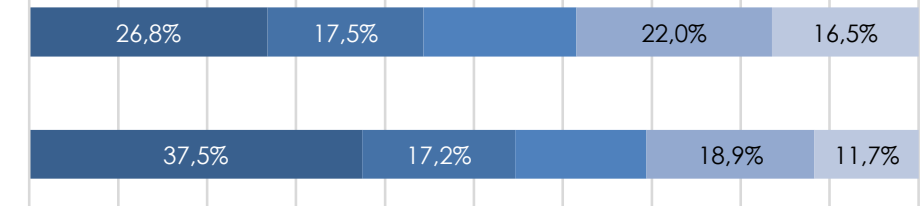

I do not have enough courage.

$17,2 \%$

$18,9 \%$

-Strongly disagree $\quad$ Disagree $\quad$ Undecided $\quad$ Agree $\quad$ Strongly agree

Source: Authors' edition

\section{Conclusion}

Our study was focused on revealing the current attitude of Hungarians towards solo tourism. As the results showed, only the minority of the respondents (ca. 15-20\%) would willing to or like to travel alone in the future, which confirms that solo tourism has not been really widespread among Hungarians. Men represent a higher proportion than women, who would take a solo trip. Analyzing the characteristics of solo traveling showed, that the survey participants see the following characteristics of solo tourism as the main advantages: escape from weekdays, feeling of freedom, and adventure.

One of the limitations of the research is that the sample is non-representative for the Hungarian population. Furthermore, the survey questions focused on only special characteristics of solo tourism based on previous studies, however, open questions could have helped reveal much deeper aspects and reasons for solo trips.

Taking travel alone is getting more and more popular among tourists, especially among Asian women. Our study aimed to analyze the Hungarians' attitude towards solo tourism. The results showed that solo tourism among Hungarians is still in its infancy, the majority of the respondents $(44,3 \%)$ have never traveled alone, and ca. 75 percent of them are not planning, either. Analyzing the answers of the different genders, we can see, that there is a significant difference between men and women in some aspects of solo tourism. Women find the spiritual aspects of solo tourism more interesting and important than men; however female tourists are more sensitive to the potential risks associated with solo tourism. This study and research investigated only a general attitude of the respondents towards this relatively new trend in tourism; nevertheless, it would be interesting to research the safety and security aspects of solo tourism deeper. This approach does have more relevance in the era of the current pandemic, too.

\section{References}

1. Abbasian, S. (2018), "Solo travellers to city destinations: an exploratory study in Sweden", International Journal of Tourism Cities, Vol. 5 No. 3, pp. 35-50. 
2. Bianchi, C. (2016), "Solo Holiday Travellers: Motivators and Drivers of Satisfaction and Dissatisfaction", International Journal of Tourism Research, Vol. 18, pp. 197-208.

3. Bond, M. (2021), "Women Travel Statistics - 80\% of All Travel Decisions Made by Women", available at: https://gutsytraveler.com/women-travel-statistics/ (19 April 2021)

4. Brown, L., Buhalis, D., Beer, S. (2020), "Dining alone: improving the experience of solo restaurant goers", International Journal of Contemporary Hospitality Management, Vol. 32 No. 3, pp. 1347-1365.

5. Chiang, C-Y., Yogaratnam, J. (2006), "Why do women travel solo for purposes of travel?", Journal Vacation Marketing, Vol. 12 No. 1, pp. 59-70.

6. Cohen, S., Gossling, S. (2015), "A darker side of hypermobility", Environment and Planning A, Vol. 47 No. 6, pp. 1661-1679.

7. Crawford, M. (2019), "Solo Travel: The Pros and Cons", available at: https://www.thebudgetmindedtraveler.com/solo-travel-pros-and-cons/ (15 February 2020)

8. Devajyoti, D. (2014), "The Living, Moving and Travel Behaviour of the Growing American Solo: Implications for Cities", Urban Studies, Vol. 51 No. 4, pp. 634-654.

9. Ernszt, I., Marton, Zs. (2020), "Nők. Egyedül. Úton. Az egyedüli utazás térhódítása a nők körében", in Varga, Z., Komáromy, M., Csákváry, T. (Ed.), III. Zalaegerszegi Egészségturizmus Konferencia Tanulmánykötet, Pécsi Tudományegyetem EGészségtudományi Kar, Egészségbiztosítási Intézet, Zalaegerszegi Képzési Központ, pp. 34-45.

10. Galik, M. (2018), "Constraints In Solo Or All Female Travel In India", Journal of Management Research and Analysis (JMRA), Vol. 5 No. 2, pp. 29-32.

11. Her, E. S., Seo, S. (2018), "Why not eat alone? The effect of other consumers on solo dining intentions and the mechanism", International Journal of Hospitality Management, Vol. 70, pp. 16-24.

12. Jordan, F., Gibson, H. (2005), "'We're not stupid... but we'll not stay home either': Experiences of solo women Travellers", Tourism Review International, Vol. 9 No. 2, pp. 195212.

13. Julieff, L. (2019), "The Pros and Cons of Solo Travel", available at: https://www.tripsavvy.com/pros-and-cons-of-solo-travel-3150761 (15 January 2020)

14. Khoo-Lattimore, C., Gibson, H. J. (2018), "Understanding women's accommodation experiences on gillfriend getaways: A pragmatic action research approach", Current Issues in Tourism, Vol. 21 No. 2, pp.1-19.

15. Laesser, C., Beritelli, P., Riklin, T. (2007), "Solo Travel - Explorative Insights from A Mature Market (Switzerland)", Travel and Tourism Research Association: Advancing Tourism Research Globally, Vol. 57, pp. 158-172.

16. Leith, C. (2020), "Tourism Trends: Lifestyle Developments and The Links to Solo Tourism", Journal of Tourism Futures, Vol. 6 No. 3, pp. 251-255.

17. Mani, G., Jose, S. (2020), "Solo Travel: A Transformative Experience for Women", Empower - The Journal of Social Work, Vol. 1 No. 1, pp. 44-56.

18. Martin, J. G. (2018), "Why more and more people are choosing to travel solo", available at: https://www.lonelyplanet.com/articles/solo-travel-asia-europe (19 April 2021)

19. Marton, Zs., Ernszt, I. (2020), "Women in Tour: Safety and Security in Focus", available at: https://uni-pen.hu/files/Konferencia/2019/Konferenciak\%C3\%B6tet_2020.pdf (21 May 2021)

20. McNamara, K., Prideaux, B. (2010), "A typology of Solo Independent Woman Travellers", International Journal of Tourism Research, Vol. 12, pp. 253-264.

21. Osman, H., Brown, L., Phung, T. (2019), "The travel motivations and experiences of female Vietnamese solo travellers", Tourist Studies, Vol. 20 No. 2, pp. 1-27.

22. Seow, D., Brown, L. (2018), "The solo female Asian tourist", Current issues in tourism, Vol. 21 No. 10, pp. 1187-1206.

23. Solo Traveler (2018a), "Solo Travelers' Travel and Spending Habits - 2018 Survey Results", available at: https://solotravelerworld.com/about/solo-travel-statisticsdata/\#2020_Reader_Survey_Results (19 April 2021) 
24. Solo Traveler (2018b), "Solo Travel Trends Report", available at: https://solotravelerworld.com/wp-content/uploads/2018/12/Solo-Travel-TrendsReport_Full_v3.pdf (19 April 2021)

25. Wilson, E., Harris, C. (2006), "Meaningful travel: Women, in-dependent travel and the search for self and meaning", Tourism, Vol. 2, pp. 161-172.

26. Wilson, E., Little, E. L. (2008), "The Solo Female Travel Experience: Exploring the "Geography of Women's Fear", Current Issues in Tourism, Vol. 11 No. 2, pp. 167-186.

\section{About the authors}

Ildikó Ernszt, Ph.D., is an associate professor at the University of Pannonia Nagykanizsa, University Center for Circular Economy, Hungary. She received her Ph.D. degree in International Law at the University of Pécs, Faculty of Law. Her research topic is the safety and security of tourism. The author can be contacted at ernszt.ildiko@uni-pen.hu

Zsuzsanna Marton is an assistant research fellow at the University of Pannonia Nagykanizsa, University Center for Circular Economy. Her university studies focused on Tourism (BA) and Marketing (MSC), which facilitated her to outline the preferred research fields such as tourism safety and security, destination image, marketing strategy, and communication. The author can be contacted at marton.zsuzsanna@uni-pen.hu 